\title{
Sandia looks for a company that will put research before profits
}

Washington. "Wanted: Manager for a US Department of Energy (DOE) national laboratory with dwindling Cold-War-related mission. Must be willing to restore tarnished image if chemical/radioactive waste problems are discovered. Compensation possible, but sense of patriotic duty preferred."

Later this year, DOE will issue an advertisement for Sandia National Laboratory that will look nothing like this, except to those who can read between the lines. American Telephone \& Telegraph (AT\&T), which has been running the Albuquerque, New Mexico, laboratory on a non-profit basis since the mid-1940s, announced last month that it would be pulling out next year (see Nature 357, 104; 1992). AT\&T had accepted the responsibility after President Harry Truman made a special appeal during the Second World War to help propel the United States into the nuclear age. But when DOE goes looking for a replacement, it may find that patriotism is no longer enough.

Realizing that running a national weapons laboratory is often a thankless task, DOE officials say that they may allow AT\&T's successor to run Sandia at a profit. If a university or university consortium decides to take over management of the laboratory (as in the case of Lawrence Livermore and Los Alamos national laboratories, which are both run by the University of California), DOE hopes to maintain the non-profit arrangement. But if a private company is the most attractive candidate, DOE is prepared to offer a deal that provides financial incentives beyond costs.

That possibility is already causing tension between the laboratory and DOE headquarters. Sandia officials are concerned that a search for profits may skew the delicate balance struck by allowing researchers as much freedom as possible within the confines of national priorities. Some incentive arrangements, which reward contractors for working closely with laboratory officials, prize cooperation above the quality of the research. And Sandia researchers are concerned that such an arrangement could compromise their independence and research objectivity.

"When we work with DOE now, they don't ever have to think about the possibility that we're being influenced by somebody's profit motive", says Lee Bray, Sandia's executive vice-president during the transition to a new contractor.

Thomas Ambrose, an official at the University of California who is renegotiating the management contracts for Lawrence Livermore and Los Alamos, says that incentive fees have their place, but not in manag- ing science. One place where Ambrose thinks that a profit is appropriate, he says, is DOE's Oak Ridge National Laboratory, which produces nuclear materials and is run by Martin Marietta Corporation for a substantial fee. Research and engineering-orientated Sandia, however, is another matter.

"If you get an incentive fee for managing

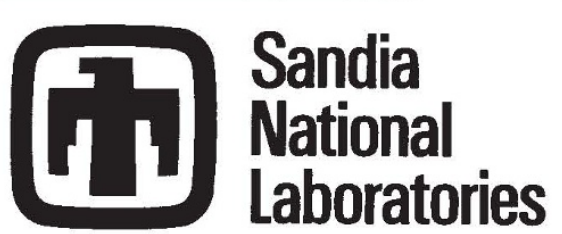

a production operation, that's not so bad", says Ambrose. "But if you start managing research and development on a fee basis, you can get into a conflict" between scientists and managers, he says.

Yet profits may be an essential element in any effort to entice a company to manage a weapons research laboratory. "It's a tough question", says Everett Beckner, assistant deputy secretary for defence programmes at DOE headquarters. "Clearly [this issue] has an overriding impact on the way the lab is regarded and managed."

Although some argue that working side by side with laboratory researchers would give a managing company insight into technology that an outside company might not recognize, a contractor is allowed no special rights to laboratory technology. Sceptics note that of the 30 Cooperative Research and Development Agreements that Sandia has signed with private companies, none has been with AT\&T.

Nevertheless, Sandia officials are optimistic that another company will find the laboratory's technology to its liking. AT\&T left because its corporate direction no longer meshed with the priorities of the laboratory, they point out, not because there was anything wrong with Sandia's research.

But Beckner gives little weight to the idea that a manager would benefit much from an inside track on laboratory technology. "If a firm came into this hoping to drag a lot of ideas out of the lab and establish a nice business, it'd be fooling itself", he says.

Although DOE will not solicit bids until the autumn, several groups are said already to be thinking about the challenge. One is a new university consortium being organised by the University of New Mexico - just the sort of group (if it can convince DOE that it could adequately manage a $\$ 1,000$ million national laboratory) that would be expected to emphasize scientific freedom over seamless bureaucracy.

Christopher Anderson

\section{Germans try to ease overcrowding}

Munich. German university students in science and mathematics are facing crowded classrooms and waiting lists for popular courses as they cope with a system creaking under the strain of rising enrolments.

The problem stems from a policy that gives any student who passes the high school graduation examination the right to higher education. Although no one wants to abandon this democratic ideal, the crisis is forcing politicians to consider changes in how the system should be funded.

Higher education is financed by the regional governments of Germany's 16 states. They, in turn, depend on the federal government for their annual budgets. This situation has in recent years led to much rhetoric but little action.

That could be changing. The cultural and finance ministers of the regional governments, while repeating their desire to retain control of education funding in the long term, have asked the federal government for
DM3,000 million (US $\$ 2,000$ million) a year for new buildings and research facilities, more teachers and larger grants to students.

More than 30,000 new teachers are needed to restore student/staff ratios to the levels that existed in 1977, says Hans-Uwe Erichsen, president of the Committee of University Principals. At Ludwig Maximillian University in Munich, for example, student/staff ratios have risen from 7.7 to 13.8 in physics, from 11.7 to 18.9 in mathematics and from 6.8 to 16.6 in biology during the past 15 years.

Erichsen wants higher education officials to meet representatives of regional and federal governments to discuss the problem. The German chancellor, Helmut Kohl, has agreed in principle but has warned that it will be hard to decide who should pay more. Another group, the Committee of Regional Presidents, will discuss the issue this summer at a special policy meeting.

Allson Abbott 